\title{
PENERAPAN MODEL PEMBELAJARAN COOPERATIVE PROBLEM SOLVING (CPS) DILENGKAPI HIERARKI KONSEP UNTUK MENINGKATKAN KREATIVITAS DAN PRESTASI BELAJAR KIMIA PADA MATERI STOIKIOMETRI SISWA KELAS X MIPA 1 SEMESTER GENAP SMA BATIK 1 SURAKARTA TAHUN PELAJARAN 2016/2017
}

\author{
Warih Puji Lestariyani ${ }^{*}$, Agung Nugroho Catur S., dan Sri Yamtinah \\ Program Studi Pendidikan Kimia, FKIP,Universitas Sebelas Maret, Surakarta, Indonesia \\ *Keperluan korespodensi, telp : 085328110119, email : warihpl3@gmail.com
}

\begin{abstract}
ABSTRAK
Penelitian ini bertujuan untuk meningkatkan kreativitas dan prestasi belajar siswa melalui penerapan model pembelajaran Cooperative Problem Solving (CPS) dilengkapi Hierarki Konsep pada materi stoikiometri bagi siswa kelas X MIPA 1 SMA Batik 1 Surakarta Tahun Pelajaran 2016/2017. Penelitian ini merupakan Penelitian Tindakan Kelas (PTK) yang dilakukan dalam dua siklus. Setiap siklusnya terdapat empat tahapan, yaitu perencanaan, pelaksanaan, observasi, dan refleksi. Subjek penelitian adalah siswa kelas X MIPA 1 SMA Batik 1 Surakarta tahun pelajaran 2016/2017. Teknik pengumpulan data melalui observasi, wawancara, kajian dokumen, angket dan tes. Teknik analisis yang digunakan dalam penelitian ini adalah deskriptif kualitatif. Berdasarkan hasil penelitian dapat disimpulkan bahwa penerapan model pembelajaran Cooperative Problem Solving (CPS) disertai Hierarki Konsep dapat meningkatkan kreativitas dan prestasi belajar siswa pada materi stoikiometri kelas X MIPA 1 SMA Batik 1 Surakarta Tahun Pelajaran 2016/2017. Pada siklus I, persentase ketercapaian kreativitas siswa sebesar $68,89 \%$ dan meningkat menjadi $80,00 \%$ pada siklus II. Persentase ketuntasan belajar aspek pengetahuan siswa pada siklus I adalah $55,56 \%$ dan meningkat menjadi $73,33 \%$ pada siklus II. Persentase ketuntasan belajar aspek sikap siswa pada siklus I adalah 92,94\% dan pada siklus II meningkat menjadi $100 \%$, serta ketuntasan belajar aspek ketrampilan siswa adalah $100 \%$.
\end{abstract}

Kata Kunci: Cooperative Problem Solving (CPS), Hierarki Konsep, kreativitas, prestasi belajar, stoikiometri

\section{PENDAHULUAN}

Perkembangan ilmu pengetahuan dan teknologi yang semakin pesat menuntut indonesia mampu melakukan perubahan guna menjawab tantangan arus globalisasi agar bangsa Indonesia mampu bersaing dengan negara lainnya. Salah satu upaya yang dilakukan pemerintah Indonesia adalah memperbaiki mutu pendidikan yang ada dengan menyusun dan mengembangkan kurikulum baru, yaitu kurikulum 2013.

Kurikulum 2013 merupakan kurikulum yang menekankan adanya peningkatan dan keseimbangan softskills dan hardskills yang meliputi aspek kompetensi sikap, ketrampilan, dan pengetahuan [1]. Karakteristik dari kurikulum 2013 sendiri adalah diterapkannya pembelajaran dengan pendekatan saintifik. Dalam pendekatan saintifik, pendekatan yang dilakukan dalam proses pembelajaran dilakukan melalui tahap mengamati, menanya, mengumpulkan data, mengasosiasi, dan mengkomunikasi.

Pembelajaran kimia idealnya harus mampu memenuhi tuntutan yang ada pada kurikulum 2013, yaitu dengan menerapkan pendekatan saintifik dalam 
proses belajar mengajar. Dalam pendekatan saintifik, pembelajaran berpusat pada siswa dimana siswa diharapkan menjadi pembelajar yang aktif. Pengetahuan dibangun oleh siswa, sedangkan guru berperan sebagai fasilitator. Namun, kenyataan yang terjadi di lapangan adalah kurang maksimalnya penerapan pendekatan saintifik dalam kegiatan belajar mengajar. Pada umumnya proses pembelajaran kimia belum sepenuhnya melibatkan siswa secara aktif seperti yang diharapkan pada kurikulum 2013.

SMA Batik 1 Surakarta merupakan salah satu sekolah yang menerapkan kurikulum 2013 dalam pelaksanaan pembelajarannya. Namun, penerapan pembelajaran yang sesuai dengan kurikulum 2013 di SMA Batik 1 Surakarta dirasa kurang maksimal. Berdasarkan hasil observasi, pembelajaran kimia di SMA Batik 1 Surakarta kurang melibatkan partisipasi aktif siswa. Siswa cenderung menjadi pembelajar yang pasif. Dalam KBM, guru menyajikan seluruh informasi yang berkaitan dengan materi pelajaran. Siswa hanya mendengarkan dan terkadang juga mencatat apa yang disampaikan guru. Pembelajaran yang dominan pada guru membuat siswa menjadi cenderung kurang aktif berpartisipasi dalam KBM. Akibatnya pembelajaran berlangsung kurang optimal sehingga hasil belajar siswa menjadi rendah. Hal ini diperkuat dengan hasil kajian data nilai rata-rata Ulangan Akhir Semester semester gasal kelas X MIPA SMA Batik 1 Surakarta tahun pelajaran 2016/2017 dimana kelas X MIPA 1 memiliki rata-rata nilai UAS mata pelajaran Kimia di bawah KKM yaitu sebesar 69,33 dengan persentase pencapaian hasil belajar adalah sebesar 33,33\%. Hanya ada 15 siswa yang tuntas dari total 45 siswa. Dari hasil tersebut, dapat dilihat bahwa capaian hasil belajar kimia di kelas $X$ MIPA 1 masih cukup rendah.

Salah satu materi pelajaran kimia yang dianggap sukar oleh siswa adalah stoikiometri. Dari hasil kajian data nilai rata-rata ulangan harian siswa kelas $X$ MIPA di SMA Batik 1 Surakarta, ketuntasan siswa pada materi stoikiometri masih cukup rendah jika dibandingkan dengan materi yang lain. Hal tersebut dapat dilihat pada Tabel 1.

Tabel 1. Data Ketuntasan Rata - rata Kelas Ulangan Harian Materi Pokok Hukum Dasar Kimia dan Stoikiometri Kelas X MIPA SMA Batik 1 Surakarta

\begin{tabular}{lcc}
\hline \multicolumn{1}{c}{ Materi } & \multicolumn{2}{c}{ Ketuntasan Rata-rata } \\
\cline { 2 - 3 } Pelajaran & $2014 / 2015$ & $2016 / 2017$ \\
\hline Hukum & $56,82 \%$ & $51,35 \%$ \\
Dasar Kimia & & \\
Stoikiometri & $36,36 \%$ & $37,84 \%$ \\
\hline
\end{tabular}

Salah satu faktor yang mempengaruhi hasil belajar peserta didik adalah kreativitas. Kreativitas siswa akan membantu siswa untuk lebih mudah untuk memahami pelajaran dan memecahkan persoalan yang ditemui dalam proses pembelajaran. Berdasarkan hasil observasi, kreativitas siswa di SMA Batik 1 Surakarta masih cukup rendah. Hal tersebut dapat dilihat ketika siswa mengerjakan persoalan yang diberikan guru. Siswa hanya mampu mengerjakan soal-soal yang mudah. Ketika level kesukaran soal dinaikkan, para siswa merasa kesulitan untuk memecahkannya. Selain itu, dalam memecahkan soal siswa hanya mengikuti langkah-langkah penyelesaian contoh soal yang diberikan oleh guru, sehingga ketika siswa menemui soal yang berbeda dengan contoh yang diberikan guru, siswa mengalami kesulitan untuk memecahkannya.

Dari berbagai masalah yang telah diuraikan di atas, dapat disimpulkan bahwa penyebab rendahnya prestasi belajar siswa SMA Batik 1 Surakarta adalah kurangnya partisipasi aktif siswa dalam kegiatan pembeleajaran. Oleh karena itu diperlukan suatu tindakan untuk memperbaiki kualitas pembelajaran sehingga prestasi belajar siswa menjadi lebih baik. Tindakan tersebut bisa berupa Penelitian Tindakan Kelas (PTK). PTK dapat diartikan sebagai penelitian tindakan (action research) yang dilakukan dengan tujuan untuk memperbaiki 
kualitas proses dan hasil belajar sekelompok peserta didik [2].

Salah satu langkah yang dapat digunakan dalam menyelesaikan permasalahan di kelas X MIPA 1 SMA Batik 1 Surakarta adalah dengan menerapkan model pembelajaran Cooperative Problem Solving (CPS). Cooperative Problem Solving (CPS) merupakan model pembelajaran dimana siswa bekerjasama dalam kelompok, berbagi ide dan membantu satu sama lain dalam memecahkan masalah yang diberikan oleh guru [3]. Gok dan Silay [4] menyebutkan bahwa penggunaan pembelajaran pemecahan masalah secara kooperatif lebih berguna jika digunakan daripada model pembelajaran konvensional. Penerapan model pembelajaran Cooperative Problem Solving (CPS) ini dirasa cocok untuk meningkatkan kreativitas dan prestasi belajar siswa kelas X MIPA 1 SMA Batik 1 Surakarta pada materi Stoikiometri. Pembelajaran Cooperative Problem Solving (CPS) menuntut siswa untuk berperan secara aktif untuk pemecahan masalah dalam proses pembelajaran. Siswa diharapkan mampu mengkonstruksi pengalamannya sendiri dalam kelompoknya. Dengan memecahkan masalah, diharapkan siswa menjadi lebih mudah untuk memahami materi sehingga prestasi belajar siswa menjadi meningkat. Penggunaan model pembelajaran Cooperative Problem Solving (CPS) dapat membuat siswa menjadi lebih kreatif [5]. Tahapan dalam pelaksanaan Cooperative Problem Solving (CPS) yaitu, pembentukan kelompok, penyampaian materi pelajaran, pengenalan masalah, pemecahan masalah, mempresentasikan hasil pemecahan masalah, menarik kesimpulan, dan evaluasi [6].

Di samping ketepatan penggunaan model pembelajaran, juga dibutuhkan media yang dapat mendukung model yang digunakan. Materi Stoikiometri berisi banyak konsep dan hukum yang saling terkait. Konsep tersebut tersusun secara hierarkis dari konsep dasar hingga konsep yang kompleks. Siswa harus dapat mengaitkan konsep yang satu dengan konsep yang lainnya sehingga siswa akan memiliki pemahaman yang utuh terhadap materi pembelajaran. Untuk mengaitkan antar konsep dibutuhkan suatu media pembelajaran yang dapat mempermudah siswa dalam belajar. Oleh karena itu, dalam penelitian ini digunakan media pembelajaran Hierarki Konsep. Hierarki konsep merupakan tingkatan dari konsep yang paling umum hingga konsep yang paling khusus [7]. Hierarki dapat direpresentasikan dalam bentuk peta konsep dan digunakan untuk menentukan urutan dalam materi pembelajaran [8]. Berdasarkan penelitian yang dilakukan oleh Damayanti [9], penerapan model pembelajaran Problem Solving disertai hierarki konsep dapat meningkatkan kreativitas dan prestasi belajar siswa. Selain itu, menurut penelitian yang dilakukan oleh Yunitasari [10], penggunaan hierarki konsep dapat mereduksi miskonsepsi siswa pada materi pokok larutan penyangga.

\section{METODE PENELITIAN}

Penelitian ini merupakan Penelitian Tindakan Kelas (PTK) yang dilaksanakan dalam dua siklus. Setiap siklusnya terdapat empat tahapan, yaitu perencanaan, pelaksanaan, observasi, dan refleksi [11]. Subjek penelitian adalah siswa kelas X MIPA 1 SMA Batik 1 Surakarta tahun pelajaran 2016/2017. Pemilihan subjek dalam penelitian ini didasarkan pada hasil observasi yang dilakukan pada saat prasiklus, dimana subjek yang dipilih tersebut teridentifikasi mempunyai permasalahan dalam pembelajaran yaitu kreativitas dan prestasi belajar yang rendah.

Data yang dikumpulkan meliputi data tentang keadaan siswa yang berupa data kualitatif dan kuantitatif. Data kualitatif diperoleh dari hasil observasi, angket, dan wawancara. Data kuantitatif didapat dari hasil penilaian prestasi belajar siswa pada materi stoikiometri yang meliputi aspek pengetahuan, sikap, dan keterampilan, serta kreativitas siswa.

Teknik analisis data pada penelitian ini menggunakan analisis deskriptif kualitatif. Teknik analisis 
kualitatif yang digunakan mengacu pada model analisis Miles dan Huberman [12] yang dilakukan dalam tiga komponen, yaitu reduksi data, penyajian data, dan penarikan simpulan. Pada penelitian ini digunakan teknik triangulasi untuk memeriksa validitas data dalam penelitian. Triangulasi adalah teknik pemeriksaan keabsahan data yang memanfaatkan sesuatu yang lain di luar data itu untuk keperluan pengecekan atau sebagai pembanding terhadap data tersebut [13]

\section{HASIL DAN PEMBAHASAN}

Berdasarkan hasil identifikasi pratindakan, kelas X MIPA 1 SMA Batik 1 Surakarta diduga mengalami permasalahan dalam rendahnya kreativitas dan prestasi belajar siswa. Oleh karena itu, diperlukan perbaikan dengan penerapan model pembelajaran Cooperative Problem Solving (CPS) dilengkapi Hierarki Konsep.

Perencanaan tindakan meliputi penyusunan instrumen pembelajaran dan instrumen penilaian. Instrumen pembelajaran meliputi silabus, Rencana Pelaksanaan Pembelajaran (RPP), dan media pembelajaran (Hierarki Konsep). Instrumen penilaian meliputi penilaian aspek pengetahuan, sikap, ketrampilan, dan kreativitas siswa.

\section{Siklus I}

Penelitian ini dilakukan dengan alokasi waktu selama 8 jam pelajaran, yang terdiri dari $6 \times 45$ menit untuk penyampaian materi stoikiometri dan $2 \mathrm{x}$ 45 menit sisanya untuk melakukan kegiatan evaluasi.

Pelaksanaan tindakan siklus I dilaksanakan selama 5 kali pertemuan. Guru mengawali kegiatan pembelajaran dengan memberikan apersepsi kepada siswa. Selanjutnya guru mengarahkan siswa untuk duduk berkelompok. Guru membagikan hierarki konsep kepada seluruh siswa. Kemudian guru menyampaikan konsep-konsep yang terkait dengan materi pelajaran. Tahap selanjutnya guru memberikan beberapa permasalahan untuk dipecahkan siswa secara berkelompok. Kemudian siswa berdiskusi dalam kelompok untuk memecahkan permasalahan yang diberikan oleh guru. Setelah siswa selesai berdiskusi dengan kelompoknya, langkah selanjutnya adalah mempresentasikan hasil diskusi di depan kelas. Setelah tahap presentasi selesai, guru menyamakan persepsi dan memberikan penguatan terhadap konsep-konsep yang telah dipelajari oleh siswa. Hal ini dilakukan untuk membuat siswa menjadi lebih paham dengan materi yang telah dipelajari. Pada akhir pembelajaran, guru membimbing siswa untuk menyimpulkan apa yang telah dipelajari. Selanjutnya guru memberikan soal post test. Pada pertemuan terakhir, dilaksanakan evaluasi akhir siklus I yang terdiri dari tes pengetahuan, tes kreativitas, dan angket sikap.

Secara umum, pelaksanaan model pembelajaran Cooperative Problem Solving (CPS) dilengkapi Hierarki Konsep pada siklus I telah berjalan dengan baik. Interaksi antara siswa dengan siswa dalam kelompok maupun interaksi antara siswa dengan guru terlihat cukup baik selama proses pembelajaran berlangsung. Dari pertemuan pertama hingga pertemuan keempat keaktifan siswa dalam pembelajaran juga sudah baik.

Data yang diperoleh dalam penelitian ini meliputi data prestasi belajar siswa pada aspek pengetahuan, sikap, keterampilan, serta kreativitas siswa.

Berdasarkan hasil tes kreativitas yang dilakukan oleh siswa kelas X MIPA 1 SMA Batik 1 Surakarta, diperoleh hasil yang dapat dilihat pada Tabel 2.

Tabel 2.Hasil Tes Kreativitas Siklus I

\begin{tabular}{lc}
\hline \multicolumn{1}{c}{ Kriteria } & Ketercapaian \\
\hline Kreativitas Tinggi & $68,89 \%$ \\
Kreativitas Sedang & $24,44 \%$ \\
Kreativitas Rendah & $6,67 \%$ \\
\hline
\end{tabular}

Berdasarkan Tabel 2, kreativitas siswa kelas X MIPA 1 SMA Batik 1 Surakarta sudah cukup baik. Persentase ketuntasan telah mencapai 
target yang telah ditentukan yaitu $65 \%$ dari jumlah total siswa memiliki kreativitas tinggi.

Pada aspek pengetahuan, siswa yang telah mencapai ketuntasan sebanyak 25 siswa (55,56\%), sedangkan siswa yang belum tuntas sebanyak 20 siswa (44,44\%). Persentase ini belum mencapai target yang telah ditentukan, yaitu siswa yang tuntas sebanyak $65 \%$ dari jumlah total siswa. Selain itu, dari 12 indikator kompetensi yang diukur terdapat 5 indikator yang belum mencapai target yang ditentukan.

Penilaian prestasi belajar aspek sikap siswa meliputi penilaian sikap spiritual dan sosial (jujur, disiplin, percaya diri, dan tanggung jawab). Berdasarkan hasil penilaian aspek sikap yang telah dilakukan, terdapat 17 siswa $(37,38 \%)$ yang prestasi belajar aspek sikapnya masuk dalam kategori sangat baik, 25 siswa $(55,56 \%)$ kategori baik, 3 siswa $(6,67 \%)$ kategori cukup, dan tidak ada siswa $(0 \%)$ yang masuk dalam kategori kurang. Dari hasil tersebut diperoleh ketuntasan sebesar 93,34\%. Hal ini sudah memenuhi target yang telah ditentukan, yaitu $75 \%$. Hasil ini menunjukkan bahwa prestasi belajar aspek sikap siswa kelas X MIPA 1 SMA Batik 1 Surakarta pada siklus I sudah cukup baik namun tetap dilakukan penilaian lagi pada siklus II untuk mengetahui peningkatan prestasi belajar aspek sikap siswa dari siklus I ke siklus II.

Penilaian prestasi belajar aspek keterampilan terdiri dari 3 aspek, yaitu kemampuan mengolah data, menalar data, dan menyajikan data. Ketuntasan prestasi belajar aspek ketrampilan siswa kelas X MIPA 1 SMA Batik 1 Surakarta sebesar $100 \%$ atau seluruh siswa tuntas. Seluruh aspek keterampilan yang diukur juga sudah mencapai target yang ditetapkan. Berdasarkan hasil tersebut dapat dilihat bahwa ketrampilan siswa kelas X MIPA 1 SMA Batik 1 Surakarta dalam mengolah, menalar, dan menyajikan data sudah cukup baik. Seluruh aspek ketrampilan yang diukur telah mencapai target yang ditentukan. Aspek menalar data memiliki ketercapaian paling tinggi, yaitu 80,97\%. Sedangkan aspek menyajikan data memiliki ketercapaian paling rendah yaitu $79,19 \%$. Nilai optimum tertinggi yang diperoleh siswa yaitu 93,8.

Berdasarkan hasil penilaian kreativitas dan prestasi belajar aspek pengetahuan, sikap, serta keterampilan dapat dilihat bahwa terdapat aspek yang belum mencapai target yang ditentukan yaitu penilaian pada prestasi belajar aspek pengetahuan. Oleh karena itu, perlu adanya tindakan lanjutan siklus II agar persentase ketercapaian seluruh indikator dapat mencapai target yang ditentukan.

\section{Siklus II}

Berdasarkan hasil refleksi dari siklus I, maka peneliti bersama dengan guru mata pelajaran kimia SMA Batik 1 Surakarta bersama-sama melakukan perencanaan tindakan pada siklus II. Siklus II lebih difokuskan untuk perbaikan terhadap kendala-kendala yang terjadi pada siklus I. Materi pelajaran yang diberikan juga difokuskan pada indikator kompetensi yang belum mencapai ketuntasan pada siklus I. Tindakan yang dilakukan pada siklus II adalah sebagai berikut, pertama adalah mengganti kelompok belajar siswa berdasarkan hasil tes aspek pengetahuan siklus I. $\mathrm{Hal}$ ini dimaksudkan agar siswa yang telah tuntas dan lebih menguasai materi dapat membantu teman satu kelompoknya apabila menemui kesulitan. Kedua, guru mengidentifikasi kesulitan belajar yang dialami siswa dengan melakukan pendekatan kepada siswa. Ketiga, guru lebih memonitoring kegiatan diskusi siswa selama proses pembelajaran. Guru berkeliling selama proses diskusi berlangsung dan guru menanyai setiap kelompok mengenai kesulitan yang dihadapi, dan yang terakhir adalah guru memerintahkan siswa untuk mengerjakan secara individu soal-soal diskusi. Hal ini dimaksudkan agar seluruh siswa memiliki jawaban dari persoalan yang diberikan guru, sehingga diharapkan hal tersebut dapat mempermudah siswa belajar. Dengan demikian, diharapkan 
hasil capaian lebih baik dan dapat mencapai target.

Siklus II dilaksanakan dalam 2 kai pertemuan. Pertemuan pertama untuk penyampaian materi dan pertemuan kedua untuk evaluasi akhir siklus II. Alokasi waktu yang digunakan adalah 5 JP.

Berdasarkan hasil tes kreativitas yang dilakukan oleh siswa kelas X MIPA 1 SMA Batik 1 Surakarta, pada siklus II diperoleh hasil 36 siswa ( $80 \%$ ) memiliki kreativitas tinggi, 8 siswa $(17,78 \%)$ memiliki kreativitas sedang, dan 1 siswa $(2,22 \%)$ memiliki kreativitas rendah. Ketuntasan belajar kreativitas siswa sebanyak 36 siswa $(80 \%)$ telah tuntas.

Pada aspek pengetahuan, seluruh indikator kompetensi yang diukur telah mencapai target yang telah ditentukan. Selain itu, ketuntasan belajar siswa juga meningkat dari siklus I, yaitu sebanyak 33 siswa $(73,33 \%)$ tuntas.

Penilaian prestasi belajar aspek sikap siswa pada siklus II dilakukan dengan cara yang sama pada penilaian aspek sikap pada siklus I, yaitu melalui observasi selama pembelajaran berlangsung dan angket penilaian diri. Dari analisis prestasi belajar aspek sikap yang dilakukan pada 45 siswa di kelas $X$ MIPA 1 SMA Batik 1 Surakarta pada siklus II, keseluruhan siswa dinyatakan tuntas. Sehingga ketuntasan untuk aspek sikap pada siklus II mencapai $100 \%$, dimana terdapat 27 siswa $(60 \%)$ prestasi belajar aspek sikapnya masuk dalam kategori sangat baik, 18 siswa $(40 \%)$ kategori baik, dan tidak ada siswa $(0 \%)$ yang masuk dalam kategori cukup maupun kurang baik.

Berdasarkan hasil penilaian kreativitas, prestasi belajar aspek pengetahuan, dan prestasi belajar aspek sikap mengalami peningkatan capaian dan sudah melampaui target sehingga penelitian di akhiri pada siklus II.

\section{Perbandingan Siklus I dan Siklus II}

Salah satu prestasi belajar yang menentukan keberhasilan pembelajaran adalah prestasi belajar aspek pengetahuan. Pada penelitian ini, penilaian prestasi belajar aspek pengetahuan dilakukan melalui tes yang dilaksanakan pada akhir setiap siklus. Hasil tes aspek pengetahuan siklus I menyatakan bahwa sebanyak 25 siswa atau $55,56 \%$ telah mencapai ketuntasan. Sedangkan jumlah siswa yang belum tuntas sebanyak 20 siswa atau $44,44 \%$. Jumlah ini belum mencapai target yang telah ditentukan, yaitu $65 \%$ dari jumlah seluruh siswa tuntas. Hasil tes aspek pengetahuan siklus II menyatakan bahwa jumlah siswa yang telah tuntas sebanyak 33 siswa atau $73,33 \%$, sedangkan jumlah siswa yang belum tuntas sebanyak 12 siswa atau 26,67\%. Dari data tersebut dapat dilihat terjadinya peningkatan persentase ketuntasan dari siklus I terhadap siklus II. Adapun peningkatan hasil tes aspek pengetahuan siklus I dan siklus II dapat dilihat pada Gambar 1.

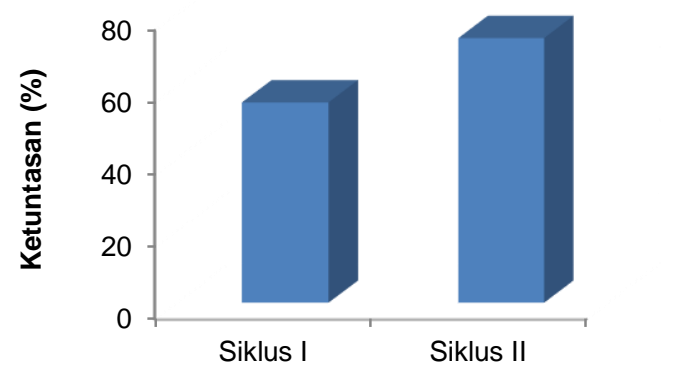

Gambar 1. Diagram Ketuntasan Prestasi Belajar Aspek Pengetahuan Siklus I dan Siklus II

Peningkatan prestasi belajar aspek pengetahuan pada siklus II disebabkan karena pada siklus II pembelajaran difokuskan pada pemberian materi untuk indikator yang belum tuntas saja. Selain itu, kelompok belajar pada siklus II ini juga diubah berdasarkan hasil tes aspek pengetahuan pada akhir siklus I. Hal ini dimaksudkan agar siswa yang telah tuntas dan telah memahami materi dapat membantu teman sekelompoknya yang belum memahami materi. Pembelajaran dengan model Cooperative Problem Solving (CPS) merupakan pembelajaran yang berpusat kepada siswa. Dalam penerapan model Cooperative Problem Solving (CPS) 
siswa dituntut berpartisipasi secara aktif saat berdiskusi bersama anggota kelompoknya untuk menemukan dan membangun konsepnya sendiri. Sehingga siswa menjadi lebih memahami materi pembelajaran.

Penilaian prestasi belajar aspek sikap dilakukan melalui angket penilaian diri dan observasi selama pembelajaran berlangsung. Rata-rata kertercapaian tiap aspek sikap siswa pada siklus I adalah $92,94 \%$ dan $100 \%$ pada siklus II. Peningkatan ketuntasan belajar prestasi belajar aspek sikap pada siklus I dan siklus II dapat dilihat pada Gambar 2

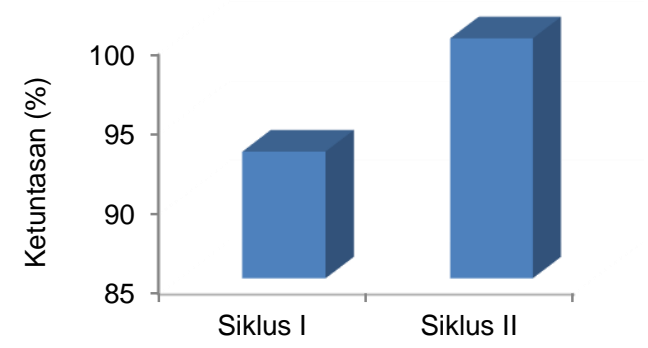

Gambar 2. Diagram Ketuntasan Prestasi Belajar Aspek Sikap Siklus I dan Siklus II

Tes kreativitas siswa dilakukan pada akhir setiap siklus. Berdasarkan hasil analisis tes kreativitas, siswa digolongkan menjadi 3 kategori, yaitu siswa yang memiliki kreativitas tinggi, siswa yang memiliki kreativitas sedang, dan siswa yang memiliki kreativitas rendah. Siswa dikatakan tuntas dalam aspek kreativitas jika siswa masuk dalam kategori kreativitas tinggi. Berdasarkan hasil tes kreativitas pada siklus I, siswa yang memiliki kreativitas tinggi sebanyak 31 siswa $(68,89 \%)$, siswa yang memiliki kreativitas sedang sebanyak 11 siswa $(24,44 \%)$, dan siswa yang memiliki kreatifitas rendah sebanyak 3 siswa $(6,67 \%)$. Sedangkan berdasarkan hasil tes kreativitas pada siklus II, siswa yang memiliki kreativitas tinggi sebanyak 36 siswa (80\%), siswa yang memiliki kreativitas sedang sebanyak 8 siswa (17,78\%), dan siswa yang memiliki kreativitas rendah sebanyak 1 siswa (2,22\%). Berdasarkan hasil tersebut dapat disimpulkan bahwa ketuntasan kreativitas siswa pada siklus I adalah sebanyak 31 siswa $(68,89 \%)$ tuntas dan pada siklus II jumlah tersebut meningkat menjadi 36 siswa $(80 \%)$ tuntas. Peningkatan ketuntasan belajar kreativitas siswa pada siklus I dan siklus Il dapat dilihat pada Gambar 3.

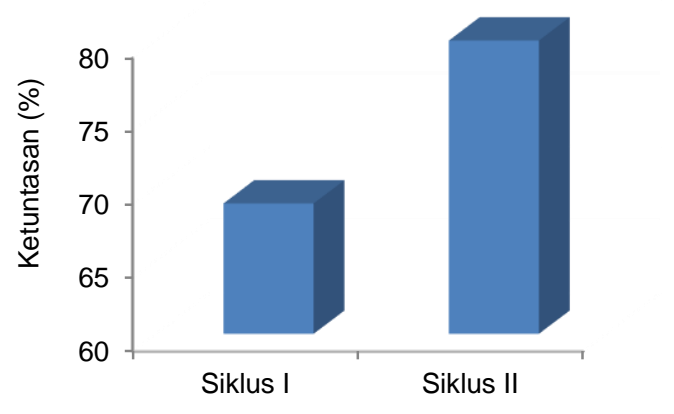

Gambar 3. Diagram Ketuntasan Kreativitas Siswa Siklus I dan Siklus II

Salah satu faktor yang menyebabkan peningkatan kreativitas siswa adalah model pembelajaran yang digunakan dalam proses pembelajaran. Penerapan model Cooperative Problem Solving (CPS) membuat siswa berpartisipasi secara aktif saat berdiskusi bersama anggota kelompoknya karena siswa dituntut untuk menemukan konsepnya sendiri. Dalam penerapan model Cooperative Problem Solving (CPS), siswa dihadapkan pada berbagai permasalahan yang bervariasi untuk diselesaikan melalui diskusi kelompok. Siswa dituntut untuk menciptakan ide-ide secara cepat terkait dengan penyelesaian masalah yang ada. Lewat diskusi tersebut, siswa bersama dengan teman kelompoknya akan mencari berbagai alternatif pemecahan masalah. Siswa akan mengaitkan rumus yang satu dengan rumus yang lain. Setelah menemukan keterkaitan antara rumus yang satu dengan rumus yang lain, maka siswa dapat menggunakannya untuk menyelesaikan masalah. Lewat proses penyelesaian masalah tersebut, siswa dapat mengembangkan kreativitasnya. 
Selain aspek pengetahuan, sikap, dan kreativitas, penilaian aspek ketrampilan siwa terhadap pembelajaran juga dilakukan. Hasil penilaian prestasi belajar aspek ketrampilan pada siklus I menunjukkan bahwa seluruh siswa telah mencapai ketuntasan sehingga tidak perlu dilakukan tindakan pada siklus II.

Dalam penelitian tindakan kelas, penelitian dapat dinyatakan berhasil apabila masing-masing indikator keberhasilan yang diukur telah mencapai target yang telah ditetapkan. Penelitian ini dapat disimpulkan berhasil karena masing-masing indikator proses dan prestasi belajar meliputi kreativitas siswa, aspek pengetahuan, dan aspek sikap yang diukur telah mencapai target dan mengalami peningkatan.

Dari hasil tindakan, pengamatan dan pembahasan dapat ditarik kesimpulan bahwa penerapan model pembelajaran Cooperative Problem Solving (CPS) disertai hierarki konsep dapat meningkatkan kreativitas dan prestasi belajar siswa pada materi stoikiometri kelas X MIPA 1 SMA Batik 1 Surakarta tahun pelajaran 2016/2017.

\section{KESIMPULAN}

Berdasarkan hasil penelitian yang telah dilakukan, maka dapat disimpulkan bahwa penerapan model pembelajaran Cooperative Problem Solving (CPS) disertai Hierarki Konsep dapat meningkatkan kreativitas dan prestasi belajar siswa pada materi stoikiometri kelas X MIPA 1 SMA Batik 1 Surakarta tahun pelajaran 2016/2017. Ketuntasan kreativitas siswa pada siklus I sebesar 68,89\% dan meningkat menjadi $80,00 \%$ pada siklus II. Pada siklus I, persentase ketuntasan belajar aspek pengetahuan siswa adalah $55,56 \%$ dan meningkat menjadi $73,33 \%$ pada siklus II. Persentase ketuntasan belajar aspek sikap siswa pada siklus I adalah 92,94 \% dan pada siklus II meningkat menjadi $100 \%$, serta ketuntasan belajar aspek ketrampilan siswa adalah $100 \%$.

\section{UCAPAN TERIMA KASIH}

Penulis mengucapkan terima kasih kepada Bapak Drs. H. Literzet Sobri, M. Pd., selaku kepala sekolah yang telah memberikan izin penelitian di SMA Batik 1 Surakarta, dan Ibu Ugik Sugiharti, S.Pd., M.Pd., selaku guru mata pelajaran kimia SMA Batik 1 Surakarta yang membantu penulis dalam penelitian ini, serta siswa kelas $X$ MIPA 1 SMA Batik 1 Surakarta.

\section{DAFTAR RUJUKAN}

[1] Fadlillah, M. (2014). Implementasi Kurikulum 2013. Yogyakarta : Arruzz Media.

[2] Mulyasa, E. (2009). Praktik Penelitian Tindakan Kelas. Bandung:PT Remaja Rosdakarya.

[3] Slavin, R. E., (1997). Educational Psychology: Theory and Practice (5th Ed). Boston : Allyu and Bacon Company.

[4] Gok,T. \& Silay,I. (2008). Egitimde Kuram ve Uygulama : Journal of Theory and Practice in Education, 4(2), 253-266.

[5] Kaptan, F \& korkmaz,H.(2002). The Effect of Cooperative Problem Solving Approach on Creativity in Science Course. Beytepe : Hacettepe University.

[6] Heller, K \& Heller, P (2010). Cooperative Problem Solving in Physics A User's Manual. [Online]. Tersedia:http://www.aapt.org/Con ferences/newfaculty /upload/Coop-Problem-SolvingGuide.pdf.

[7] Novak, J.D.\& Gowin, D.B. (2008). Learning How To Learn. New York : Cambridge University Press. 
[8] Herron, J.D., et al. (1997). Science Education, 61(2), 185-199.

[9] Damayanti, D.R., Saputro, A. N. C., \& Yamtinah, S. (2014). Jurnal Pendidikan Kimia, 3(4), 118-125.

[10] Yunitasari, W., Susilowati, E., \& Nurhayati, N. D. (2013). Jurnal Pendidikan Kimia, 2(3), 182-190.
[11] Arikunto, S. (2012). Penelitian Tindakan Kelas. Jakarta: Bumi Aksara.

[12] [12]Miles, M.B. \& Huberman, A.M. (1995). Analisa Data Kualitatif. Jakarta: UI Press.

[13] Moleong, L.J. (2000). Metodologi Penelitian Kualitatif. Bandung : Remaja Rosdakarya 